\title{
PENGANALISAAN WILAYAH DAN PERTUMBUHAN KEBUDAYAAN TINGGI DI SUMATRA SELATAN
}

\section{Oleh: DR. John N. Miksic (Jurusan Arkeologi Fakultas Sastra UGM)}

Walaupun seorang ahli arkeologi terkenal pernah mengemukakan suatu hipotesa bahwa pusat kerajaan Sriwijaya mungkin tidak terletak di sekitar kota Palembang, Sumatra Selatar, ,! namun kebanyakan data arkeologi masih mendukung kesimpulan bahwa daerah sekitar Bukit Seguntang dan pertemuan antara Sungai Musi, Ogan, dan Komering, tidak terlalu jauh dari suatu kraton di antara tahun 682 sampai $1082 \mathrm{M} 2$. Di dalam karangan ini akan dipegang suatu asumsi bahwa daerah sekitar Palembang pernah merupakan suatu pusat kekuasaan politik pada awal masa Klasik, yang dikenal dengan nama Sriwijaya.

Masalah yang akan dibahas di sini merupakan tinjauan terhadap dua hipotesa saling bertentangan yang berupaya menjelaskan faktor penyebab utama dalam perkembangan situs tersebut. Suatu hipotesa yang lebih sering diajukan, yaitu bahwa faktor utama yang telah mendukung perkembangan Palembang pada awal jaman Klasik adalah kedudukannya yang terletak pada suatu jalur perhubungan internasional antara Samudra Hindia, Laut Cina Selatan, dan Indonesia bagian timur. Hipotesa tersebut sebenarnya hanya dikemukakan sebagai suatu asumsi, karena tanpa disertai dengan usaha untuk mendukungnya. Di bawah ini akan kami ajukan hipotesa kedua, yang menyatakan bahwa faktor keadaan setempat di Sumatra Selatan harus diberi pertimbangan sebagai suatu sumber daya yang paling menentukan dalam persoalan tersebut.

Patut disayangkan bahwa sampai sekarang faktor-faktor yang bertanggungjawab atas pertumbuhan situs perkotaan di Indonesia pada zaman klasık belum jelas. Antara laın, kita belum tahu bagaimana bentuk pola pemukıman pada salah sebuah situs pemukiman padat pada kurun waktu sebelum kedatangan agama Islam ke Indonesia. Oleh karena berlakunya keadaan itu, setiap usaha untuk menggambarkan proses urbanisasi tradisional di Indonesia yang dilakukan atas dasar data yang tersedia sampai tahun 1984 terpaksa ditinggalkan pada tingkat yang awam sekali. Untuk memenuhi keperluan karangan ini, akan ditarik asumsi bahwa $\mathrm{Pa}$ lembang pada kurun waktu antara 682-1082 $\mathrm{M}$ telah merupakan pusat dari sebuah sistem perdagangan dan komunikasi, sedangkan jumlah penduduk di pusat tersebut belum dapat diperincikan. Seandainya survei pencarian situs pemukiman nanti dilakukan di wilayah tersebut, baru dapat dibahas 
titik persamaan di antara Palembang dengan situs kota Klasik Indonesia lain seperti Trowulan, misalnya dari segi jumlah penduduk dan jenis kegiatan yang dilakukan di dalamnya. Perbandingan semacam itu dapatimeng hasilkan manfaat yang tidak sedikit, karena akan menimbulkan kebolehan agar ditemukan sifat pokok dari proses pembentukan situs kota dan juga kebudayaan klasik atau peradaban tinggi di wilayah Nusantara, dan persamaan atau perbedaan di antara urutan perkembangan di sini dengan urutan yang diamati pada tempat lain seperti Cina atau India. Pertumbuhan kebudayaan tinggi di Indonesia sering dilihat sebagai akibat dari proses komunikasi, difusi, pertumbuhan sekunder, dan sebagainya ${ }_{3}^{3}$ Kalau nanti ditemukan bukti bahwa faktor setempat telah menduduki tempat terdepan dalam proses perkembangan tersebut, berarti pandangan umum yang sudah lama diterima tersebut akan terpaksa mengalami perubahan menyeluruh.

Asumsi umum tentang peranan perdagangan asing dalam pertumbuhan pusat kerajaan Sriwijaya di Palembang terlihat dengan jelas pada sebuah karangan dari Dr. Bennet Bronson, Penyantun Asia Tenggara, Field Museum, Chicago (Amerika Serikat) (Gambar 1). Beliau pernah melukis sebuah diagram yang dimaksud sebagai wakil dari bentuk umum yang ditunjukkan oleh jaringan : komunikasi yang berlaku di Sumatra Selatan pada zaman Klasik.4. Di dalam modelnya, pola pemukiman dan kegiatan perdagangan diperkîrákan dibentuk oleh aliran sungai. Menurut asumsinya, pusat pemukiman dan kegiatan perdagangan harus ditemukan di dekat muara sungai pada Selat Melaka atau Selat Bangka. Di wilayah hulu, pada muara di mana sungai induk dimasuki dan ditemui oleh anak sungai, akan ditemukan pusat tingkat dua dan tingkat tiga. Menurut kedudukannya pada jaringan komunikasi tersebut, dan di daerah paling hulu, di atas bentangan sungai terakhir yang dapat dilalui dengan alat angkutan air, akan ditemukan kelompok-kelompok peramu yang bekerja mencari rotan, damar, emas, gading gajah, tanduk badak, dan komoditi tradisional lain yang disalurkan kepada konsumen di luar pulau Sumatra (di India dan Cina) melalui pelabuhan besar di pinggir pantai. Dalam gagasan Bronson, perkembangan pelabuhan besar tersebut bergantung seluruhnya pada permintaan akan Komodıtıtertentu oleh kerajaan besar luar Indonesia.5 Maka tanpa permintaan dari luar, pusat pemukiman dan peradaban tersebut idak akan muncul. Jadi perkembangan kebudayaan Klasik Sumatra ditentukan oleh faktor luar pulau itu.

Pola yang digambarkan Dr. Bronson sangat menyerupai suatu pola yang ditemukan oleh para ahli geografi kebudayaan dan disebutnya dengan istilah dendritic (dari bahasa Yunani Kuno, berarti "'pohon"). Istilah ini diterapkan karena gambar pola perhubungan ini mirip dengan sebatang pohon, yang semakin tinggi semakin bercabang hingga beranting. Aspek 
paling penting dari gagasan ini terdiri dari kenyataan bahwa di antara ranting dan cabang, atau cabang dan batang pohon, hanya terdapat salah satu titik penyambung. Dalam contoh geografi, ini berarti bahwa para penduduk pada suatu desa tidak dapat memilih antara beberapa pusat pemasaran; pola pemasaran ditentukan oleh jalur komunikasi yang hanya berjalan searah. Seorang pengumpul rotan pada hulu anak sungai " A" misalnya tidak bisa menjual hasil peramuannya kepada para tengkulak di anak sungai 'B' karena tidak terdapat prasarana jalan. Maka para pembeli menguasai sistem pemasaran,tanpa persaingan antara beberapa pembeli untuk memperoleh komoditi yang sama. Harga komoditi dikuasai oleh para pembeli atau tengkulak, dan harga penjualan kebutuhan pokok kepada penduduk di hulu ditentukan oleh para penjual.

Menurut suatu studi yang dilakukan di Malaysia Barat, pola perhubungan dan pemasaran yang mirip dengan sistem dendritic juga ditemukan di sana. Memang topografi di sana mempunyai persamaan dasar dengan Sumatra Selatan: bentangan tanah yang panjang dan sempit, dengan dataran rendah berupa endapan Holocene di sepanjang pantai barat dan timur, dan suatu deretan pegunungan di tengah-tengah. Kelompok-kelompok peramu di daerah hulu melakukan pertukaran barang-barang di antara kelompoknya di tanah tinggi melalui jalur yang menelusuri lereng gunung, sedangkan komoditi tertentu dikumpul di hutan khusus untuk dijual kepada "pedagang tingkat dua" di pinggir hutan, hulu sungai, atau ujung jalan. Pedagang tingkat dua kemudian bertemu pada tempat-tempat tertentu di sekitar pantai, di mana komoditi tersebut dijualnya kepada "pedagang tingkat tiga" di kota-kota pesisir.6

Pola dendritic sering ditemukan pada daerah bekas penjajahan, di mana pada zaman dulu kegiatan utama merupakan pertambangan atau penanaman komoditi perkebunan untuk diekspor ke luar negeri, seperti karet, gula, kapas, kopi, timah, dan sebagainya. Para penjajah yang memiliki hak monopoli tidak berusaha untuk membangun jalan-jalan antara desa di pedalaman; mereka hanya ingin menciptakan pola pengangkutan yang akan memperlancar pengeluaran komoditi dari tempat produksi di pedalaman sampai ke pelabuhan. Jadi, pernah dinyatakan bahwa pola dendritic ' 'nampaknya dapat ditemukan terutama pada daerah jajahan atau bekas jajahan di mana pemasaran telah dipaksakan oleh suatu kelompok asing yang terlibat dalam pemasaran luar negeri dan perdagangan ekspor-impor." 7 Pernah juga diajukan teori bahwa pola tersebut telah berlaku untuk pulau Jawa. ${ }^{8}$

Jadi, seandainya teori Bronson tentang pola penyebaran situs-situs kota pelabuhan dengan pemukiman di pedalaman ternyata didukung oleh data arkeologi, maka kita harus menerima kesimpulan bahwa perdagang- 
an luar negeri memang pernah merupakan faktor utama dalam proses pertumbuhan kota di Indonesia. Walaupun data arkeologi masih kurang lengkap, pola yang diajukan Bronson dapat diuji dengan data yang ada sampai sekarang untuk memastikan apakah hipotesanya didukung atau tidak.

\section{Pengujian Hipotesa Dendritic}

Selain situs Palembang, masih terdapat sebuah lokasi lagi yang rupanya pernah memainkan peranan penting dalam sejarah Klasik Awal di Sumatra, yaitu Muara Jambi.Kedua situs tersebut tidak berlokasi pada pinggir pantai, melainkan jauh di pedalaman; Muara Jambi terletak $85 \mathrm{~km}$. dari laut, dan Palembang $90 \mathrm{~km}$. Menurut suatu teori, kedua situs tersebut memang masih berada di sekitar pantai pada kurun waktu 1.500 tahun lalu, sewaktu pusat perdagangan semula didirikan di sana, ${ }^{9}$ tetapi penelitian lebih lanjut telah menghasilkan data yang menimbulkan keraguan mengenai kebenaran teori tersebut. ${ }^{10}$ Bentuk garis pantai di daerah Sumatra Timur dan juga letak aliran sungai-sungai kemungkinan besar telah mengalami pergeseran besar selama dua ribu tahun belakangan ini, tetapi tidak mencapai yang mencukupi untuk mendukung hipotesa bahwa situs Palembang telah dipilih sebagai ibukota kerajaan Sriwijaya karena letaknya berada dekat pantai.

Di sekitar muara Sungai Musi pada hari ini terdapat sebuah desa bernama Sungsang, yang sudah dihuni selama beberapa ratus tahun. ${ }^{11} \mathrm{Me}$ nurut suatu laporan dari awal abad 19, penduduk Sungsang "telah bekerja sebagai pengawal muara sungai, menyelidiki kapal-kapal dagang yang masuk Sungai Musi, dan berlayar ke Palembang kalau harus menyampaikan berita penting. 12 Maka penduduk sekitar muara Sungai Musi pernah melakukan beberapa tugas yang berkenaan dengan perdagangan laut, akan tetapi tidak pernah mendirikan sebuah situs kota atau pusat politik yang penting; karena mereka selalu patuh pada pusat kerajaan yang terletak 90 kilometer ke hulu.

Menurut hipotesa Bronson, dan juga ketentuan dari teori dendritic, penduduk di daerah hulu, dari sebuah jaringan perhubungan dan komunikasi harus terisolir dari penduduk pada hulu sungai lain, dan tebih dari satu pusat kegiatan yang lebih besar dari desa mereka. Pengamatan secara cermat juga menghasilkan keterangan yang bertentangan dengan hipotesa tersebut. Antara lain kita memiliki informasi bahwa pada zaman tradisional, situs-situs di pedalaman sudah dihubungi lewat jalur-jalur komunikasi pada lereng Bukit Barisan, sehingga penduduk di hulu Sungai Musi dapat berjalan kaki sampai ke ulu Rawas, atau penduduk dataran tinggi Pasemah dapat memilih antara beberapa jalan ke pantai, baik ke arah timur laut maupun barat daya. Jadi para peramu hutan di Sumatra berkesempatan 
umtuk memilih antara beberapa pusat pemasaran atau penimbunan supaya menjual hasilnya dan agar mencari komoditi penting dari luar seperti kain, garam dan besi. ${ }^{13}$ Memang sumber kita untuk mendukung kesimpulan tadi semua berasal dari abad 18 dan 19, akan tetapi dapat dianggap bahwa informasi tersebut mewakili masa yang lebih tua lagi di Sumatera. Penelitian arkeologi lebih lanjut mungkin akan memberikan keterangan yang lebih terperinci mengenai jalur perhubungan darat di Sumatera pada masa sebelum kedatangan orang-orang Eropa ke sana.

Sebagai kesimpulan, dapat dikemukakan pendapat bahwa teori Bronson maupun model dendritic secara prima facie tidak didukung oleh data yang ada. Maka kita tidakterikat pada asumsi bahwa perkembangan pusat-pusat peradaban di Sumatra : merupakan akibat dari faktor yang berasal dari luar pulau Sumatra, , terutama karena terletak pada jalur perdagangan internasional. Lalu dapat diajukan hipotesa kedua, bahwa faktor setempat secara otomatis mampu mendorong manusia yang bertempat tinggal di Sumatra Selatan untuk menciptakan suatu pusat kegiatan di Palembang.

\section{Faktor Setempat Yang Mendukung Kebudayaan Tinggi Sumatra Selatan}

Dalam penelitiannya mengenai asal-usul kerajaan Sriwijaya, beberapa faktor pernah ditunjuk oleh Prof. Dr. O.W. Wolters, karena dianggapnya menguntungkan wilayah Sumatra Tenggara dalam perbandingan dengan daerah pesisir Sumatera lain: ' pelabuhan-pelabuhannya, pangkalan-pangkalannya yang aman, jaringan-jaringan sungai yang menciptakan jalur perhitungan dengan daerah pedalaman, dan jalur rawa yang membentang jauh ke pedalaman dan memberikan perlindungan terhadap serangan dari darat." '14 Sebenarnya, situs Palembang maupun Muara Jambi tidak terletak di sebelah hilir rawa, melainkan di sebelah hulu; maka tidak mungkin bahwa daerah rawa telah melindungi penduduk kedua situs tersebut dari serangan orang hulu. Kalau suatu lokasi yang terletak 90 kilometer ke arah pedalaman memiliki pelabuhan yang dekat dengan jalur angkutan laut, mengapa tidak mendirikan pelabuhan itu di pinggir pantai, yang 90 kilometer lebih dekat lagi dengan jalur tersebut? Sebenarnya, pernyataan tentang perlindungan dari serangan yang berasal dari pedalaman justeru bertentangan dengan pengamatan beliau bahwa keadaan geografis Sumatra Tenggara memang memperlancar hubungan antara situs Palembang dengan daerah hulu.

Beberapa faktor lain dapat dipertimbangkan dalam rangka upaya untuk menilai ciri-ciri alam yang terdapat pada masing-masing wilayah di Sumatra: supaya menemukan ciri yang mampu memberikan keunggulan pada daerah Palembang. Termasuk di sini adalah kesuburan tanah (yang ternyata berbeda antara setiap lembah sungai di Sumatra menurut jenis 
batuan di hulunya), 15 dan pola penyebaran sumber-sumber bahan tertentu (termasuk emas, perak, damar, dan lain sebagainya). Di sini hanya akan dibahas salah satu faktor, yaitu kedudukan Palembang pada suatu jaringan perhubungan yang mampu mengendalikan lalu lintas antara tiga kesatuan wilayah: tanah tinggi Sumatra bagian barat, yaitu Pegunungan Barisan; daerah kaki bukit atau piedmont dan pertemuan anak sungai sewaktu memasuki dataran rendah Sumatra Tenggara; dan daerah pesisir timur laut.

\section{Penganalisaan Lokasi dan Situs Palembang}

Beberapa tahun lampau suatu tanggapan buku geografi telah ditulis oleh seorang arkeolog terkenal, C. Renfrew, dan menurut pendapat beliau, gagasan yang terkandung dalam istilah ' penganalisaan lokasi (locational analysis) atau "'penafsiran wilayah"' regional analysis) perlu sekali diteliti oleh para ahli arkeologi, karena banyak diantaranya berpotensi amat besar untuk memperluas jangkauan data di bidang tersebut. ${ }^{16}$ Dengan penerapan beberapa gagasan dan metode penganalisaan data dari bidang studi ini, kita akan memperoleh suatu penilaian objektif tentang pengaruh ciri-ciri alam dari lembah Sungai Musi terhadap pertumbuhan kebudayaan tinggi di sana. Kalau kita meninjau berbagai contoh dari kebiasaan manusia dalam mempergunakan ruang dalam kegiatannya, dapat disimpulkan bahwa beberapa keseragaman sudah tampak secara terlepas sama sekali dari faktor politik, seperti masalah penjajahan, atau penguasaan perdagangan laut.

Suatu unsur yang ditemukan pada hampir setiap teori mengenai tingkah laku manusia dalam penggunaan ruang merupakan gagasan tentang susunan pusat-pusat kegiatan dan pemukiman yang dapat disusun dari yang besar sampai yang kecil. Pusat-pusat kegiatan maupun pemukiman selalu memiliki jalur berhubungan dengan pusat atau wilayah lain, dan pertukaran informasi, bahan dan tenaga selalu akan mengikuti jalur tersebut. Maka pusat-pusat kegiatan juga merupakan titik pertemuan antara beberapa jalur yang membentuk suatu jaringan untuk penyaluran perhubungan dan juga pertukaran bahan. Tinggi atau rendahnya suatu pusat dalam suatu susunan atau "hierarchy" dari seluruh pusat yang terikat dalam suatu jaringan langsung bertalian dengan jumlah dan besarnya pusat-pusat lain yang berhubungan dengannya.

Menurut penelitian yang sudah dilakukan, ukuran besar suatu pusat yang dihitung berdasarkan jumlah penduduknya, memiliki korelasi ynag tinggi dengan jumlah kegiatan yang dilakukan di dalamnya. Maka status sebuah pusat dari segi jumlah penduduk dapat diasumsikan akan menunjukkan status yang hampir sama dengan status yang diperlihatkan kalau dihitung dengan jumlah kegiatan. Angka kependudukan sudah gampang diperoleh, sedangkan angka tentang jumlah kegiatan belum banyak dikum- 
pul untuk kota-kota di Indonesia. Jadi korelasi tersebut memiliki nilai tinggi untuk membantu penganalisaan data di sini. Hipotesa tentang korelasi tersebut telah diuji di daerah pedesaan baik di belahan bumi timur maupun barat, dan ternyata tetap didukung. ${ }^{17}$ Karena itu, kita dapat menggunakan angka kependudukan dari kota-kota di Sumatra, supaya kedudukannya dalam hierarchy pusat-pusat kegiatan (termasuk ekonomi dan politik) di Sumatra pada saat-saat tertentu dapat dipastikan.

Menurut satu asumsi pokok dalam pendekatan penafsiran lokasi, setiap orang akan berusaha agar pengeluaran tenaga dalam rangka usaha untuk memperoleh kebutuhan hidup diirit sejauh mungkin, dan pola penyebaran pusat-pusat kegiatan manusia (desa, kota, pasar) akan mencerminkan ciri tersebut. Di dalam keadaan yang paling sederhana, di mana terdapat keadaan tanah yang datar; penyebaran kependudukan dan sumber daya merata; dengan sistem ekonomi didasarkan atas sistem tawar-menawar untuk menentukan harga'(price-fixing markets) dan penggunaan uang sebagai alat tukar, di samping usaha dari semua pedagang untuk memperoleh keuntungan maksimal; maka pola penyebaran pusat-pusat kegiatan harus memperlihatkan bentuk segi-enam. 18

Dalam kenyataan, kondisi seperti itu jarang atau tidak pernah ditemui; sehingga pola penyebaran yang dijumpai merupakan penyimpangan dari gagasan ideal dalam segi topografi, penyebaran sumber daya, dan kependudukan, di samping kebiasaan manusia dalam mengatur kehidupan ekonomi yang tidak "rasional", dalam arti tidak ditujukan pada pengumpulan keuntungan yang semaksimal mungkin. Semua kemajuan yang tercapai dalam penerapan prinsip "'pengeluaran tenaga minimal untuk keuntungan maksimal" atau principle of least effort kepada contoh kasus merupakan keberhasilan dalam penentuan pengaruh dari penyimpangan tertentu dalam satu atau sekelompok variabel tersebut (topografi, kependudukan, struktur sosio-ekonomi).

Namun, di luar dugaan, sejumlah kasus telah ditemukan, di mana pola penyebaran pusat-pusat pemukiman mirip sekali dengan teori. Suatu penerapan modal tersebut 'yang termashur di wilayah Asia telah menunjukkan kekuatannya untuk menjelaskan faktor-faktor yang mampu me= nentukan penyebaran pusat pemasaran enam wilayah pedesaan di negara Cina. ${ }^{19}$

Model segi-enam tersebut juga cukup luwes sehingga dapat disesuaikan dengan perubahan dalam hubungan antara pusat-pusat dari tingkat tinggi dan rendah pada suatu susunan hierarchy. Satu variabel penting, seperti dicatat tadi, merupakan jumlah pusat tingkat tinggi yang dapat dihubungi dari satu pusat tingkat rendah. 
Kalau sebuah pusat tingkat rendah, misalnya sebuah desa, memiliki jalur perhubungan dengan tiga pusat pada tingkat satu lagi di atasnya, misalnya tiga kota kecamatan, masing-masing terletak pada jarak yang sama, kemudian desa tersebut akan memiliki keunggulan bahwa penduduknya dapat memanfaatkan perbedaan harga di antara ketiga-tiganya, menjual hasilnya di mana diperoleh harga tertinggi, dan membeli kebutuhannya di mana terdapat harga terrendah.Keadaan ini oleh seorang ahli geografi dijuluki ' bentang darat pemasaran' atau marketing landscape (gambar 2a). Keadaan seperti itu menguntungkan para penduduk desa, dan sering ditemukan dalam contoh kasus di mana kebanyakan penduduk masih hidup di desa, dan sarana transportasi masih mahal dan sederhana. ${ }^{20}$

Pada contoh kedua, suatu desa hanya memiliki hubungan dengan dua kota. Dalam keadaan ini, penduduk desa tersebut memiliki pilihan yang lebih terbatas dari segi pencarian harga yang bersaing, akan tetapi ongkos transportasi mereka akan diperkecilkan juga karena perjalanan mereka akan menjadi lebih jarang. Oleh para ahli geografi keadaan ini disebut bentang tanah transportasi (transport landscape) (gambar 2b).

Dalam keadaan ketiga, setiap desa hanya akan memiliki hubungan dengan salah sebuah kota, sehingga, yang beruntung di sini adalah penduduk kota, bukan desa. Contoh ini disebüt "'bentang tanah administratif' dan dengan ini dicerminkan keadaan politik yang berlaku pada negara negara zaman modern, di mana setiap pusat pemukiman berada di bawah satu pusat pemerintaharr saja (gambar $2 \mathrm{c}$ ).

Ketiga contoh tadi memperlihatkan perbedaan dalam pola perhubungan antara desa dan kota yang timbul karena perbedaan dalam pola ekonomi, pemasaran, dan pengangkutan. Di luar variasi umum tadi, masih dapat digambarkan tipe-tipe yang lebih banyak menurut perbedaan dalam perhubungan antara pusat pada tingkat.sama, misalnya antara satu desa dengan desa lain.

Persediaan jalur perhubungan, pengangkutan, dan pemasaran dapat diukur dengan beberapa cara, tetapi variabel terpenting di sini disebut connectivity, berarti kepadatan jalur komunikasi pada satu wilayah tertentu. Suatu angka yang disebut Beta index dapat dipakai untuk memastikan hubungan antara jumlah pusat kegiatan/pemukıman, pada satu pihak, dan jumlah jalur-jalur alternatif yang terdapat antaranya. ${ }^{21}$ Angka tertinggi untuk Beta index adalah tiga, tetapi nilai-nilai di atas satu sudah berarti bahwa setiap pusat atau sudut dari satu jaringan perhubungan akan mempunyai lebih dari dua jalan keluar. 22 Pola perhubun an dengan Beta index di bawah nilai satu dapat disamakan dengan bentans tanah admınıstratit, karena dalam setiap kasus, satu pusat tingkat rendah tidak memiliki pilihan dalam hal pengeluaran hasilnya. Di negara-negara yang sedang berkembang, sering 
ditemukan Beta index dibawah satu, berarti bahwa pola perhubungan ini menunjukkan keadaan ekonomi dengan kegiatan yang masih pada tingkat rendah. 23

Selain dari connectivity (daya penghubung) dari sebuah sistem, dapat dilihat dua aspek lain dari suatu jaringan perhubungan, dengan implikasi terhadap lembaga politik dan sosial: tingkat pemusatan atau centrality, dan bentuk dari sebuah jaringan. Keterperincian ini dalam menggambarkan sistem perhubungan dapat membantu para ilmuwan membedakan antara tipe-tipe jaringan perhubungan yang ada, dan penerapannya pada contoh kasus juga dipermudahkan.

Seorang ahli geografi bernama Kansky pernah menciptakan suatu rumusan sederhana yang dapat menghasilkan suatu angka dengan pertalian bermakna terhadap bentuk dasar dari sebuah jaringan perhubungan. ${ }^{24}$ Angka petunjuk bentuk tersebut terbukti memiliki korelasi tinggi dengan tingkat pengembangan ekonomi, termasuk Hasil Domestik Bruto per jiwa. 25

Akhirnya dapat dikemukakan suatu rumusan lagi, yaitu angka Konig. Angka ini dihitung hanya dengan menghitung jumlah pusat lain dalam suatu jaringan yang harus dilewati seorang dalam perjalanan dari satu ujung ke ujung kedua dari jaringan tersebut. Satu-satunya lokasi dengan angka Konig terrendah akan merupakan pusat dari jaringan komunikasi itu secara geografis. ${ }^{26}$ Jadi angka Konig tersebut tidak hanya menunjukkan suatu ciri dari sebuah sistem pada keseluruhannya, tetapi menghasilkan pula suatu nilai perbandingan untuk setiap lokasi dalam jaringan tersebut.

Dengan menerapkan teori tadi pada Sumatra Selatan, kita akan memperoleh suatu petunjuk obyektif mengenai daya pengaruh jaringan transport lokal terhadap perkembangan kebudayaan tinggi. Menurut teori arkeologi, salah satu faktor penting dalam penciptaan peradaban tinggi merupakan lancarnya hubungan antara manusia. ${ }^{27}$ Kemungkinan, faktor komunikasi merupakan sesuatu yang lebih penting dari pola pemukiman, yaitu peralihan dari kehidupan di desa kepada urbanisasi, atau peralihan dari sistem pemerintahan tradisional atas dasar adat atau tribe dalam istilah Service ${ }^{28}$ sampai sistem negara atau state. Akan tetapi walaupun kita mempunyai beberapa contoh tulisan kuno dari wilayah Sumatra maupun Jawa, kebanyakan naskah sudah hilang pada masa silam karena keadaan iklim basah dan bahan mudah lapuk. Jadi usaha merekonstruksi jaringan komunikasi masa lampau harus bergantung lebih banyak untuk sementara kepada pendekatan teori dan sumber data analogi, dibanding dengan daerah lain di mana data arkeologi sudah mampu berdiri sendiri sebagai petunjuk tentang jalur-jalur pemasaran lokal. 29

Menurut teori Bronson, Beta index dari sistem komunikasi di Sumatra harus: mencapai angka kurang dari satu, karena hanya terdapat salah 
satu jalur yang dapat diikuti antara sepasang pusat kegiatan dalam jaringan tersebut. Dalam gambar 1 misalnya terdapat 8 lokasi dan hanya tujuh jalur di antaranya; maka Beta index adalah 7 dibagi 8 atau 0,875 . Angka ini merupakan petunjuk bahwa sistem tersebut hanya dapat dikuasai dari salah satu tempat strategis, sehingga cenderung mendukung sistem monopoli.

Seperti sudah diuraikan di atas, laporan dari abad 18 dan 19 memuat data bahwa jalur antara situs desa di pedalaman sudah ada, yang tidak harus melewati sungai, melainkan lereng gunung. Sekurang-kurangnya akan ditambah jalur antara keempat situs D pada gambar 1, berarti bahwa rumusan tadi menjadi 10 dibagi 8, atau 1,25. Angka di atas satu sudah merupakan petunjuk bahwa jaringan komunikasi tersebut bersifat majemuk, atau kompleks. Memang sulit untuk memastikan Beta Index yang benar untuk daerah Sumatra Selatan pada abad ketujuh, karena lokasi situs belum banyak diketahui, apa lagi jalur komunikasi yang terdapat di antaranya. Bagaimanapun menurut perkiraan, sistem perdagangan setempat di Sumatra Selatan pada awal abad 19 belum memperlihatkan perubahan prinsip dibanding dengan masa-masa lebih awal. 30 Jadi dapat diasumsikan bahwa laporan dari para pengamat sebelum tahun 1850-an belum menggambarkan keadaan yang jauh berbeda dengan masa sebelumnya. Sampai ke mana asumsi ini dibenarkan baru dapat dipastikan dengan peningkatan data arkeologi.

Dari segi centrality atau kecenderungan supaya kegiatan di wilayah Sumatra Selatan dipusatkan pada tempat tertentu, rumusan dimulai dengan mencari jumlah pusat yang harus dilalui oleh seorang penumpang dalam perjalanan dari ujung satu sampai ke ujung kedua dari jaringan tersebut; kemudian dijumlahkan jarak antara seluruh pusat dalam sistem tersebut, dan akhirnya jarak total dibagi dengan jumlah pusat yang harus dilewati dalam perjalanan yang terpendek. Hasilnya akan merupakan suatu angka yang berhubungan dengan bentuk jaringan komanikasi tersebut. Rumusan ini sudah diterapkan pada berbagai kasus di dunia, dan ternyata bahwa negara-negara berkembang seperti Perancis memiliki angka sekitar 30 , sedangkan untuk suatu negara yang sedang berkembang angka tersebut dapat mendekati satu. Jadi angka ini dianggap suatu petunjuk peka terhadap keadaan ekonomi yang ditunjang oleh suatu jaringan transport. ${ }^{31}$

Dalam contoh kasus Sumatra Selatan, jarak sungai yang dapat diewati oleh kapal-kapal di atas bobot mati 5 ton pada musim kemarau kirakira $1.010 \mathrm{~km} .{ }^{32}$ Jalan darat yang menghubungkan Pulau Panggung di hulu Sungai Komering dengan Kotatanjung di hulu Sungai Rawas berjumlah kira-kira $250 \mathrm{~km}$.; maka jarak keseluruhan yang termasuk dalam jaringan Sumatra Selatan berjumlah sekitar $1.260 \mathrm{~km}$. Angka terbesar untuk perjalanan dari ujung Kotatanjung ke ujung Cahayanegeri adalah 7 pusat yang harus dilewati. Dua jalur dapat diikuti untuk sampai ke Cahayane- 
gari dari Kotatanjung, lewat sungai $(370 \mathrm{~km})$ atau darat $(330 \mathrm{~km})$, sehingga jumlah rata-rata adalah $350 \mathrm{~km}$. Kemudian angka 350 dikonversi ke dalam baku mil, jadi $350 \times 0,6$ atau sama dengan 210; kalau dibagi 7 (jumlah pusat yang dilalui dalam perjalanan tersebut), maka dihasilkan angka 30, atau sama dengan angka dari negara Perancis yang dianggap bertalian dengan ekonomi dan perhubungan yang maju dan lancar.

Akhirnya kita akan mencari angka Konig yang merupakan petunjuk mengenai letak pusat kegiatan paling efisien dalam sebuah jaringan perhubungan. Sebenarnya angka tersebut dap at disamakan dengan jumlah pusat yang perlu dilewati untuk berjalan dari satu pusat kepada setiap pusat lain dalam sebuah jaringan, seperti yang sudah dihitung untuk perjalanan dari Kotatanjung ke Cahayanegeri. Hanya di sini angka tertinggi tidak dicari, melainkan angka terrendah karena dianggap bahwa letak sebuah pusat dari jaringan akan berada di tempat yang paling efisien karena dapat dicapai dari setiap pusat lain dalam waktu yang paling sedikit, sesuai dengan prinsip "least effort"' tadi.

Dalam jaringan Sumatra Selatan, ternyata bahwa angka tertinggi, 7, dimiliki oleh daerah-daerah di hulu, sedangkan angka terrendah, 5, hanya diperoleh di dua pusat, Muaraenim dan Palembang (lihat gambar 3). Berdasarkan keterangan tersebut, tanpa data lain, akan diramalkan bahwa kedua lokasi itu akan unggul dibanding semua pusat lain dalam jaringan komunikasi itu sebagai calon pusat tertinggi. Dalam rumusan Konig, ternyata bahwa wilayah muara sungai atau desa Sungsang mempunyai angka lebih tinggi, yaitu 6, berarti statusnya sebagai pusat tingkat tiga dalam hierarchy wilayah dapat dimengerti kalau diterima kesimpulan bahwa sistem wilayan di daerah. Sumatra Selatan didasarkan atas sebuah jaringan komunikasi setempat, dan bukan ditimbulkan karena pengaruh komunikasi dengan pusat-pusat asing di seberang laut.

Tentu saja, faktor penganalisaan wilayah ini tidak dapat berdiri sendiri. Faktor lain perlu dipertimbangkan pula, seperti topografi, kesuburan tanah, dan penyebaran sumber-sumber daya, di samping sistem sosio-ekomi tradisional, karena semua faktor ini dapat mempengaruhi pola kegiatan yang dilakukan pada suatu jaringan komunikasi. Di sini tidak dapat diuraikan panjang lebar mengenai faktor-faktor tersebut karena kekurangan waktu dan tempat; cuma dapat diperlihatkan sebagai data perbandingan suatu peka dari zaman penjajahan Belanda yang menunjukkan pusatpusat administrasi di wilayah|Sumatra Selatan. Ternyata bahwa di antara angka Konig dan tingkat masing-masing tempat terdapat korelasi tinggi antara kedudukan administratif tinggi dan angka Konig rendah, artinya pusat-pusat administrasi Belanda terletak dekat pusat yang paling efisien dari segi komunikasi. Letaknya pusat administrasi kolonial Belanda juga 
meniru bentuk dari penyebaran pusat kekuasaan pada zaman Kesultanan Palembang, sehingga diperkirakan bahwa pola tersebut masih mempunyai nilai untuk menggambarkan keadaan politik tradisional pada masa yang lebih tua lagi.

\section{KESIMPULAN}

Seperti diisyaratkan oleh para ahli sejarah, Sumatra Selatan tidak memiliki sumberdaya penting dalam perdagangan internasional pada awal zaman Klasik, pusat penghasilan damar, kapur barus, dan sebagainya terletak di Sumatra Utara. ${ }^{33}$ Maka tidak logis kalau pusat pengekspor untuk komoditi tersebut terletak begitu jauh dari pusat produksinya. Perkembangannya lokasi Palembang sebagai pusat pemerintahan Sriwijaya lebih masuk akal kalau dianggap bahwa faktor setempat berupa jaringan komunikasi dan kegiatan lalulintas, tukar-menukar informasi dan bahan dengan frekwensi tinggi sudah terbentuk lebih dulu, dan sudah berhasil mendorong manusia setempat sehingga menciptakan suatu pola kebudayaan yang bersifat peradaban. Pada tahap perkembangan sejarah lebih lanjut, di mana arus lalu lintas antara Indonesia, India, dan Cina ditingkatkan, manusia tersebut sudah siap untuk memanfaatkannya karena sudah trampil dalam hal administrasi dan juga pelayaran untuk mencari sumberdaya baru dari luar negeri. Mungkin tidak hanya merupakan kebetulan bahwa situs praklasik terbesar di Sumatra Selatan, Pasemah, dan tidak terletak jauh dari Muaraenim, yang tidak kalah dari Palembang dalam segi lancarnya perhubungan dengan situs lain dalam jaringan komunikasi setempat. Mungkin suatu pergeseran pernah terjadi dari wilayah Pasemah pada akhir prasejarah kepada pusat pemerintahan di Palembang pada awal Klasik sebagai akibat dari peningkatan perhubungan antara Sumatra Selatan dan dunia luar; tetapi faktor setempat masih unggul sebagai faktor penentu dalam sistem wilayah, karena pusat jaringan tersebut tetap terletak pada wilayah pedalaman.

Tingkat kepercayaan dari kesimpulan tentang pengaruh letak Palembang dalam jaringan komunikasi setempat pada awal Klasik belum dapat dipastikan karena kekurangan data dari pedalaman Sumatra. Selama masa Islam, ternyata bahwa faktor setempat masih cukup kuat untuk ditunjuk sebagai landasan kedudukan tertinggi Palembang dalam sistem ekonomi dan politik Sumatra. Maka perlu dicari data lagi untuk mendukung atau menolak hipotesa ini untuk masa yang lebih tua. Selanjutnya diharapkan agar metode penganalisaan data ini dapat diterapkan kepada masalah di bagian lain dari Indonesia, di Jawa misalnya. Pendekatan ini memiliki potensi cukup tinggi untuk mengungkapkan masalah yang sedang dihadapi oleh arkeologi di Indonesia, seperti disinyalir oleh Renfrew lebih dari 10 tahun lalu. 


\section{CATATAN KAKI}

1. B. Bronson, "'A lost kingdom mislaid", Bulletin, Field Museum of Natural History 46/4, 1975: 16-20.

2. O.W. Wolters, "A note on the capital of Srivijaya during the eleventh century", in. B. Shin, J. Boisselier, dan A.B. Griswold, red., Essays Offered to G.H. Luce (Ascona: Artibus Asiae, 1966, 2 jilid), I: 225-239; E.E. McKinnon, 'Spur-marked Yueh-type sherds at Bukit Seguntang", Journal of the Malaysian Branch of the royal Asiatic Society : 52/2, 1979: 41-47.

3. Lihat misalnya P. Wheatley, Pivot of the Four Quarters (Chicago: Aldine, 1971.

4. B. Bronson, 'Exchange at the upstream and downstream ends: notes toward a functional model of the coastal state in Southeast Asia', dalam K. Hutterer, red., Economic Exchange and Social Interaction in Southeast Asia Anm Arbor: University of Michigan. Papers on South and Southeast A sia no. 13, 1977, 39-54, dencan gambar, hal +2 .

5. Lirrat gambar 1.

6. F.L. Dunn, Rain-Forest Collectors and Traders (Kuala Lumpur:IMalaysıa Branch, Ruyal Asiatic Society, Monograph No. 5, 1975), khusus halaman 95, 100 (gambar 7.I) dan hal. 113.

7. C.A. Smith, "Economics of marketing systems: models from economic geography, Annual Review of Anthropology, 3, 1974! ( hal.:167-201), 178.

8. C.A. Smith, 'Exchange systems and the spatial distribution of elites', dalam C.A. Smith, red., Regional Analysis (New York: Academic Press, 1976, 2 jilid), jilid II, hal. 310-374, hal. 368, tabel 2.

9. R. Soekmono, 'Geomorphology and the location of Srivijaya', Madjalah IImu-ilmu Sastra Indonesia 1/1, 1963, hal. 78-90.

10. J.N. Miksic, "Archaeology and palaeogeography in the Straits of Malacca', in K. Hutterer, op.cit., hal. 155-175; J.N. Miksic Archaeology, Trade, and Society in Northeast Sumatra (Cornell University: Ph. D. Dissertation, 1979); O.W. Wolters, 'Landfall on the Palembang coast in early mediaeval times", Indonesia 20, 1975: hal. 1-55.

11. O.W. Wolters, 'Landfall on the Palembang coast in early mediaeval tımes', Indonesia 20, 1975, hal. 1-55; O.W. Wolters, "A note on Sungsang village at the estuary of the Musi River in southeastern'Sumatra: a reconsideration of the historical geography of the Palembang region', Indonesia 27, 1979: hal. 33-50.

12. M.O. Woetders, Het Sultanaat Palembarg 1817-1825 (The Hague: Verhandelingen van het Koninklijk Instituut voor Taal, Landen Volkenkunde no.172, 1975); O.W. Wolters, A note on Sungsang village', hal. 49.

13. J.B. Neumann, 'Het Pane-en Bila-stroomgebied", Tijdschrift van het Koninklijk Aardrijkskundig Genootschap jilid 2 no. 1, serie kedua, 1856 (hal. 1-33), hal. 69-70; A. FreyWissseling, ''Over de zand steppen van Kota Pinang ter O.K. van Sumatra', Tropisch Natuur jilid 22 (1933: hal. 69-72), hal. 71; W. Marsden, The History of Sumatra (London: Longman, 1811); J. Anderson, Mission to the East Coast of Sumatra in 1823 (Kuala Lumpur: Oxford University Press, 1971), hal. 83, 250, 263; C. Dobbin, 'Economic 
change in Minangkabau as a factor in the rise of the Padri movement, 1784-1830", Andonesia $23(1-38)$, hal. 8.

14. O.W. Wolters, Early Indonesia Commerce (1thaca: Cornell University Press, 1967), hal. 225 dan 342 catatan kaki 163; dengan menyebut juga N.J. Krom, Hindoe-Javaansche Geschiedenis.

15. E.C. Mohr, The Soils of Equatorial Regions (Ann Arbor: J.W. Edwards, diterjemahkan oleh J.M. Pendleton, 1944).

16. C. Renfrew, 'Review of Peter Haggett: Locational Analysis in Human Geography", Antiquity 43/169 (1969): hal. 74-75.

17. Untuk suatu contoh di Sri Lanka, lihat Gunawardene, Service Centres in Southern CeyIon (University of Cambridge: Ph. D. Thesis, 1964), cited in P. Haggett, Locational Analysis in Human Geography (New York: St. Martin's Press, 1966), hal. 115, 212.

18. W. Christaller, Central Places in Southern Germany, Englewood Cliffs: Prentice Hall, 1966, diterjemahkan oleh C.W. Baskin).

19. G.W. Skinwer,'’Marketing and social structure in rural China', Journal of Asian Studies $24 / 1$, hal. $3-43,1964 ; 24 / 2,195-228,1965$.

20. C.A. Smith, "Reginal economic systems", in C.A. Smith, red., Regional Analysis, jilid I, (hal. 3-63) hal. 20.

21. Haggett, op.cit., hal. 238-239.

22. Lihat gambar pada Haggett, op. cit., 8.15.

23. K.J. Kansky, 'Structure of Iransport networks: relationships between network geometry and regional characteristics", University of Chicago, Departement of Geography Research Papers no. 84, 1963, dikutip dalam Haggett, op.cit., hal. 71.

24. Kansky, op.cit., Haggett, op.cit. hal. 70.

25. Kansky, op.cit., hal. 28-29; Haggett, op.cit., hal. 237-238.

26. Haggett, idem.

27. R.J. Wenke, 'Explaining the evolution of cultural complexity: a review', dalam M.J. Schiffer, red., Advances in Archaeological Method and Theory, jilid 4, New York: Academic Press, 1981, hal. 79-127.

28. E.R. Service, Origins of the State and Civilization (New York: W.W. Norton, 1975).

29. G.A. Johnson, 'Locational analysis and the investigation of Uruk local exchange systems", dalam J.A. Sabloff dan C.C. Lamberg-Karlovsky, red., Ancient Civilization and Trade (Albuquerque: University of New Mexico, 1975), hal.' 285-340.

30. J.C. van Leur, Indonesian Jrade and Society (The Hague: van Hoeve, 1955) hal. 6567, 117; O.W. Wolters, The Fall of Srivijaya in Malay History (Ithaca: Cornell University, 1970), hal. 177; M.A.P. Meilink-Roelofsz, Asian Trade and European Influence in the Indonesian Archipelago (The Hague: M. Nijhoff, 1962), hal. 10-11.

31. Haggett, op.cit., hal. 240.

32. Dihitung dari Robert R. Nathan Associates, reproduksi dari Bonn University Report on South Sumatra Infrastructure, 1976, exhibits 3 dan 4.

33. Wolters, Early Indonesian Commerce; P.Wheatley!' Geographical notes on some commodities involved in Sung maritime trade", Jiow rnal of the Malaysian Branch of the Royal Asiatic Society 32/2, 1959; Wang G.W., 1958, "The Nanhai trade", Journal of the Malaysian Branch of the Royal Asiatic Society $31 / 2$. 


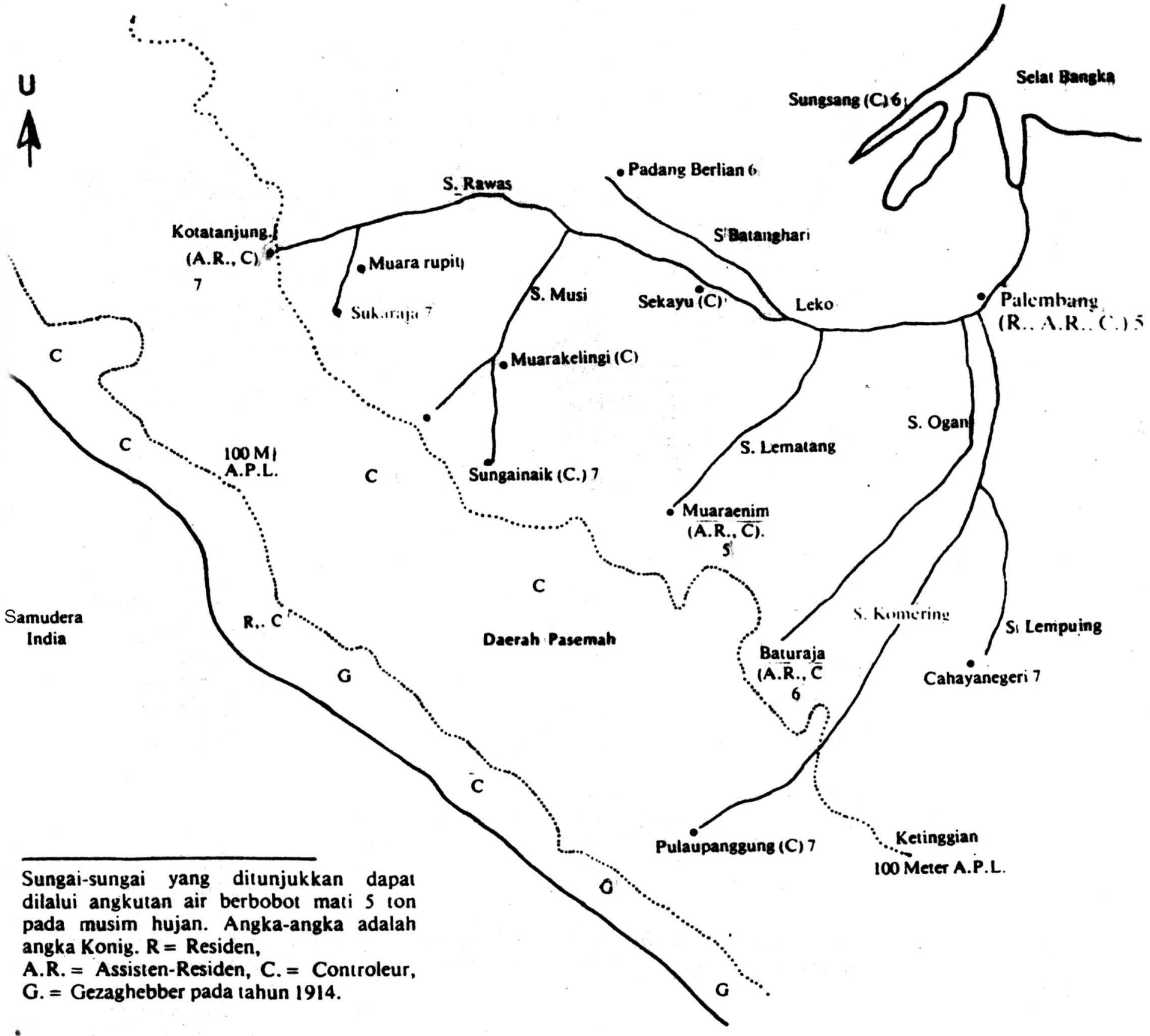



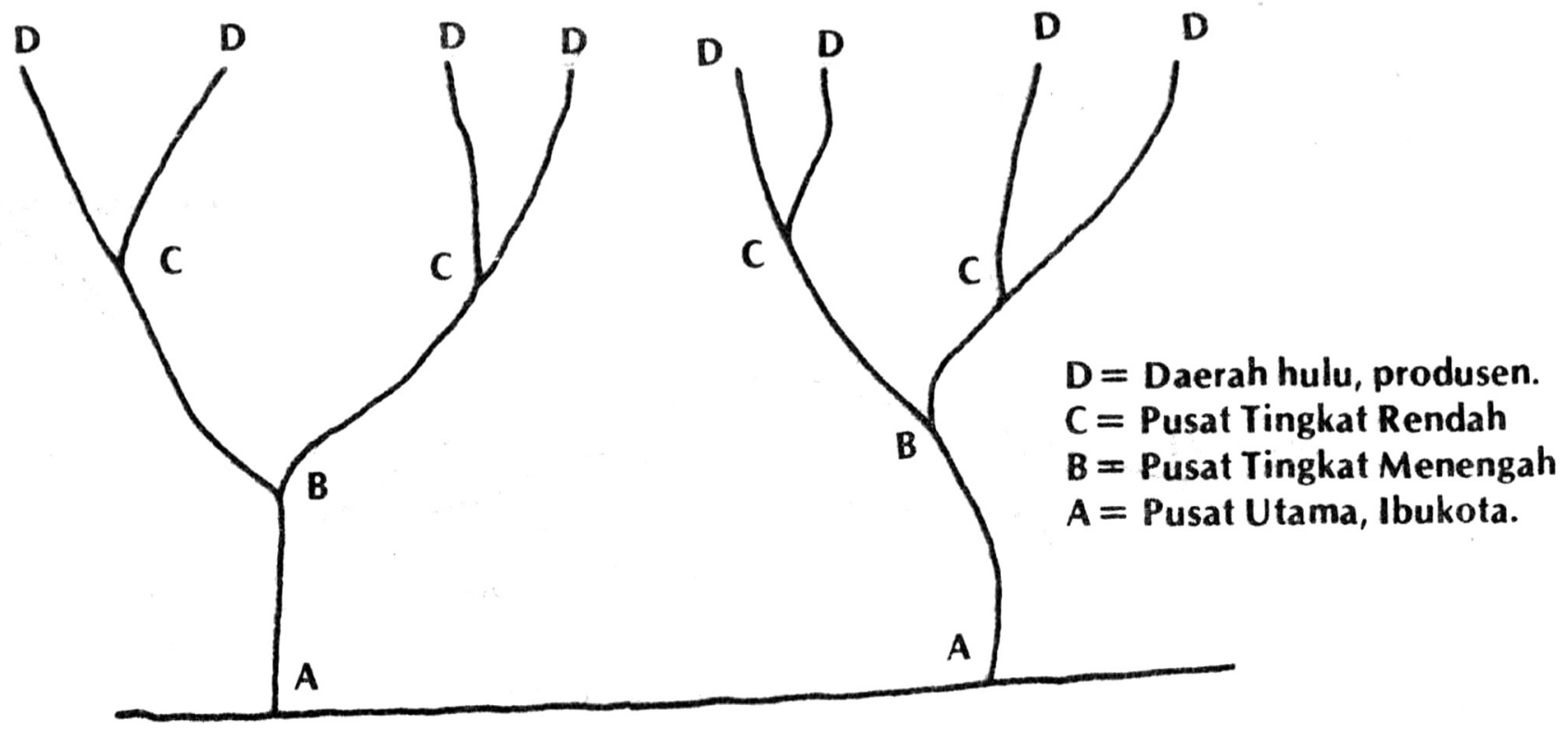

Laut

Gambar 1. Model Bronson atau Dendritic.
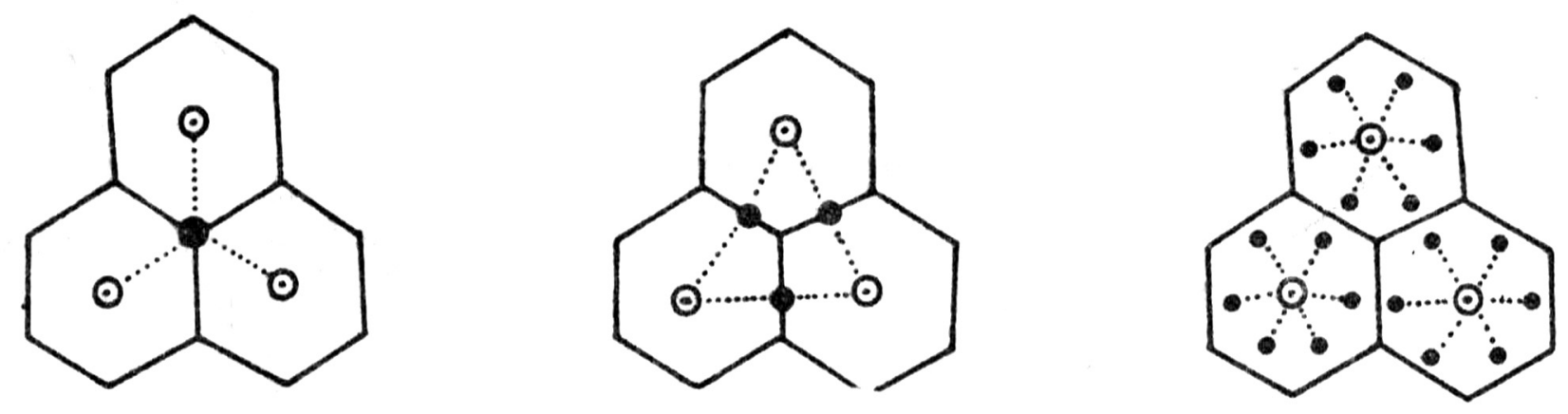

- Pusat Tingkat Tinggi (misalnya kota).

- Pusat Tingkat Rendah (misalnya desa)

a. Bentangan Tanah Pemasáran (Marketing Landscape) b. Bentangan Tanah Transports. (Transport Landscape) c. Bentangan Tanah Administratif. (Administrative Landscape)

Gambar 2. Tipe Bentangan Tanah Menurut Christaller. 